\title{
MENYELESAIKAN SOAL MATEMATIKA MODEL PISA LEVEL 4
}

\author{
Kamaliyah, Zulkardi, Darmawijoyo
}

\begin{abstract}
Abstrak
PISA (Program International for Student Assessment) merupakan suatu program penilaian skala internasional yang bertujuan untuk meneliti kemampuan siswa usia 15 tahun dalam menerapkan pengetahuan yang sudah mereka pelajari di sekolah, yang berfokus pada bidang membaca, matematika, dan sains. Berdasarkan hasil PISA tahun 2009, distribusi skor literasi matematika siswa Indonesia belum mencapai level 4. Selanjutnya, dari hasil PISA 2012 untuk bidang matematika, kurang dari 5\% siswa Indonesia yang mampu menjawab soal level 4 , yaitu soal-soal yang berhubungan dengan model untuk situasi yang konkret tetapi kompleks dan mengintegrasikan representasi yang berbeda serta menghubungkannya dengan situasi nyata. Oleh karena itu, tujuan dari penelitian ini adalah untuk mengetahui bagaimana siswa menyelesaikan soal matematika model PISA Level 4. Metode penelitian yang digunakan adalah penelitian kualitatif. Jenis penelitian ini lebih menekankan pada deskripsi secara menyeluruh dan mengidentifikasi kesulitan siswa dalam menyelesaikan soal matematika model PISA level 4. Sebanyak 26 siswa kelas IX SMPN 1 Palembang, 17 siswa kelas IX F dan 20 siswa kelas IX G SMP Xaverius 1 Palembang terlibat dalam penelitian ini. Hasil penelitian menunjukkan bahwa siswa kesulitan dalam (1) memberikan penjelasan dan mengomunikasikannya berdasar pada interpretasi mereka, dan (2) menghubungkan representasi yang mereka peroleh dengan situasi dunia nyata. Siswa tidak kesulitan ketika bekerja secara efektif dengan model dalam situasi yang konkret tetapi kompleks, serta dalam memilih dan mengintegrasikan representasi yang berbeda.
\end{abstract}

Kata Kunci: PISA, literasi matematika, soal matematika model PISA level 4.

\section{Pendahuluan}

PISA merupakan suatu program penilaian skala internasional yang dilaksanakan oleh OECD (Organisation for Economic Co-operation \& 
Kamaliyah, Zulkardi, Darmawijoyo

Development) dan Unesco Institute for Statistics. PISA bertujuan untuk meneliti secara berkala kemampuan siswa usia 15 tahun (kelas IX SMP dan Kelas X SMA) dalam menerapkan pengetahuan yang sudah mereka pelajari di sekolah yang berfokus pada bidang membaca (reading litercy), matematika (mathematics literacy), dan sains (science literacy) (Yusuf, 2007). Penelitian yang dilakukan PISA meliputi lima periode, yaitu tahun 2000, 2003, 2006, 2009, dan 2012.

Orientasi PISA mencerminkan perubahan dalam tujuan dan sasaran kurikulum, yang lebih menekankan tentang apa yang dapat dilakukan siswa, daripada apa yang telah mereka pelajari di sekolah, dan tidak hanya memperhatikan apakah mereka telah menguasai materi tertentu. Oleh karena itu, diharapkan siswa dapat memiliki kemampuan literasi matematika (mathematical literacy).

Dalam OECD (2009) dijelaskan definisi dari literasi matematika (mathematical literacy), yaitu:

Mathematical literacy is an individual's capacity to identify and understand the role that mathematics plays in the world, to make well-founded judgements and to use and engage with mathematics in ways that meet the needs of that individual's life as a constructive, concerned and reflective citizen.

Dari definisi ini, dapat dikatakan bahwa di dalam PISA, siswa diminta untuk merefleksi dan mengevaluasi materi, tidak hanya untuk menjawab pertanyaan-pertanyaan yang memiliki jawaban (benar) tunggal. Seseorang dikatakan memiliki tingkat literasi matematika apabila ia mampu menganalisis, bernalar, dan mengomunikasikan pengetahuan dan keterampilan matematikanya secara efektif, serta mampu memecahkan dan menginterpretasikan penyelesaian masalah matematika dalam berbagai situasi.

Dengan demikian, pengetahuan dan pemahaman tentang konsep matematika sangatlah penting. Akan tetapi, lebih penting lagi adalah kemampuan untuk mengaktifkan literasi matematika tersebut untuk 
JPM IAIN Antasari

Vol. 1 No. 1 Juli - Desember 2013, pp. 1-8

memecahkan permasalahan yang dihadapi dalam kehidupan sehari-hari. Oleh karena itu, soal-soal yang diberikan dalam PISA disajikan sebagian besar dalam konteks situasi dunia nyata, sehingga dapat dirasakan manfaat dari matematika.

Indonesia adalah salah satu negara yang terlibat dalam PISA. Pada PISA tahun 2000, Indonesia menempati ranking 39 dari 41 negara untuk bidang matematika; dengan skor 367 yang jauh di bawah skor rata-rata Negara OECD, yaitu 500. Pencapaian dalam bidang matematika siswa Indonesia pada PISA 2003 masih belum memuaskan, yaitu ranking 38 dari 40 negara; dengan skor 361. Pada PISA 2006, skor matematika siswa Indonesia naik menjadi 391, akan tetapi Indonesia tetap berada di ranking bawah, yaitu ranking 50 dari 57 negara. Pada PISA 2009, skor matematika siswa Indonesia turun menjadi 371, dengan ranking 61 dari 65 negara (Wijaya, 2012). Pada PISA 2012, skor matematika siswa Indonesia sedikit naik menjadi 375, namun berada di posisi 64 dari 65 negara peserta (OECD, 2013).

Berdasarkan hasil PISA tahun 2009 (Stacey, 2011), distribusi skor literasi matematika siswa Indonesia belum mencapai level 4. Selanjutnya, dari hasil PISA 2012 untuk bidang matematika (OECD, 2013), kurang dari $5 \%$ siswa Indonesia yang mampu menjawab soal level 4 , yaitu soalsoal yang berhubungan dengan model untuk situasi yang konkret tetapi kompleks dan mengintegrasikan representasi yang berbeda serta menghubungkannya dengan situasi nyata, dengan rata-rata skor siswa Indonesia adalah 375, yang termasuk dalam level 1. Oleh karena itu, penelitian ini berfokus pada pertanyaan: Bagaimana siswa menyelesaikan soal matematika model PISA Level 4.

\section{Metode Penelitian}

Metode penelitian yang digunakan dalam studi ini adalah penelitian kualitatif. Penelitian kualitatif adalah studi penelitian yang menyelidiki kualitas hubungan, kegiatan, situasi, atau materi. Jenis 
Kamaliyah, Zulkardi, Darmawijoyo

penelitian ini lebih menekankan pada deskripsi yang holistik, menggambarkan secara rinci semua yang terjadi di dalam kegiatan atau situasi tertentu daripada membandingkan efek dari pengobatan tertentu atau menggambarkan sikap atau perilaku orang. Ada lima langkah dalam penelitian kualitatif (Fraenkel \& Wallen, 2010): (1) identifikasi fenomena yang akan dipelajari - siswa kesulitan dalam menyelesaikan soal matematika model PISA level 4, (2) identifikasi subjek dalam studi - 26 siswa kelas IX 2 SMPN 1 Palembang, 17 siswa kelas IX F, dan 20 siswa kelas IX G SMP Xaverius 1 Palembang (3) generasi hipotesis - siswa dapat bekerja secara efektif dengan model dalam situasi yang konkret tetapi kompleks, memilih dan mengintegrasikan representasi yang berbeda, memberikan penjelasan dan mengomunikasikannya berdasar pada interpretasi dan tindakan mereka, serta menghubungkannya dengan situasi dunia nyata, (4) pengumpulan data - menggunakan lembar kerja siswa dan mewawancarai beberapa siswa untuk mendapatkan informasi yang lebih dalam dari proses berpikir mereka, (5) analisis data - data dianalisis dengan deskripsi holistik, dan (6) interpretasi dan kesimpulan - mengacu pada level kemampuan matematika dalam PISA untuk menafsirkan dan membuat kesimpulan.

\section{Hasil dan Pembahasan}

Siswa diminta untuk menyelesaikan dua buah soal matematika model PISA level 4. Soal-soal tersebut telah divalidasi dari segi konten, konstruk, dan bahasa menggunakan penelitian pengembangan tipe formatif evaluation (Tessmer, 1993) dengan tahapan expert review, one-to-one, small group, dan filed test.

Kemampuan matematika siswa dalam PISA dibagi menjadi enam tingkatan, dengan tingkatan 6 sebagai tingkat pencapaian yang paling tinggi dan 1 yang paling rendah. Setiap tingkatan tersebut menunjukkan tingkat kompetensi matematika yang dicapai siswa. Pada level 4, para siswa dapat bekerja secara efektif dengan model dalam situasi yang konkret tetapi kompleks, memilih dan mengintegrasikan representasi yang berbeda, dan 
JPM IAIN Antasari

Vol. 1 No. 1 Juli - Desember 2013, pp. 1-8

menghubungkannya dengan situasi nyata. Para siswa pada tingkatan ini juga dapat menggunakan keterampilannya dengan baik dan mengemukakan alasan dan pandangan yang fleksibel sesuai dengan konteks, mereka dapat memberikan penjelasan dan mengomunikasikannya disertai argumentasi berdasar pada interpretasi dan tindakan mereka (OECD, 2009; OECD, 2010; OECD 2013).

\section{Soal Nomor 1}

\section{GERHANA MATAHARI}

Gerhana matahari terjadi ketika posisi bulan terletak di antara bumi dan matahari sehingga menutup sebagian atau seluruh cahaya matahari.

Berdasarkan informasi dari situs internet gerhana matahari akan terlihat pada tanggal 25 September 2012 di Afrika Selatan dan Selandia Baru.

Diketahui perbedaan waktu Afrika Selatan dengan waktu Greenwich 2 jam lebih cepat, sedangkan perbedaan waktu Selandia baru dengan waktu Greenwich 13 jam lebih cepat.

Menurut pendapatmu, apakah informasi dari situs internet tersebut masuk akal? Berikan penjelasan untuk mendukung jawabanmu!

\section{Konten : Perubahan dan Hubungan \\ Konteks : Ilmiah}

Dengan penggunaan konteks gerhana matahari, diasumsikan bahwa siswa sudah mengenal gerhana dan mengerti perbedaan waktu di beberapa tempat. Penyelesaian soal ini memerlukan alat matematika yang sederhana dan menggunakan representasi yang berbeda. Soal tersebut memerlukan beberapa matematisasi yang dimulai dengan mengidentifikasi matematika yang relevan. Pertanyaannya sederhana sehingga hanya memerlukan operasi yang sederhana (penjumlahan bilangan asli). Jadi, kesulitan soal ini terletak pada matematisasi: pertama, siswa harus mengidentifikasi perbedaan waktu antara Afrika Selatan dan Selandia Baru (11 jam). 
Kemudian mereka harus menerapkan perbedaan waktu ini pada situasi yang baru (gerhana matahari).

Berdasarkan indikator soal PISA level 4, pada soal ini siswa bekerja secara efektif dengan model yang eksplisit di mana diketahui gerhana matahari akan terlihat di dua tempat yang berbeda dengan perbedaan waktu yang telah disebutkan. Siswa perlu memilih dan mengintegrasikan representasi yang berbeda, yaitu perbedaan waktu antara Afrika Selatan dan Selandia Baru yang tidak dinyatakan secara langsung melainkan melalui waktu Greenwich serta menghubungkannya secara langsung dengan kenyataan mengenai kejadian gerhana matahari. Kemampuan yang baik dalam beralasan secara fleksibel dengan beberapa pengetahuan tentang gerhana matahari digunakan untuk menilai apakah masuk akal gerhana matahari akan terlihat di kedua negara tersebut. Kemudian siswa perlu membangun dan mengomunikasikan penyelesaian berdasarkan argumen, interpretasi, dan tindakan mereka untuk memberikan penjelasan yang dapat mendukung jawabannya.

Siswa A menjawab soal ini dengan menuliskan hubungan antara waktu Afrika Selatan, Greenwich, dan Selandia baru seperti ditunjukkan Gambar 1. Hal ini menunjukkan bahwa Siswa A mampu membuat persamaan untuk situasi yang konkrit tetapi kompleks dan mampu mengintegrasikan informasi pada soal, kemudian membuat hubungan berdasarkan informasi tersebut. Siswa A juga telah menggunakan kemampuan yang baik dalam beralasan secara fleksibel serta membangun dan mengomunikasikan penyelesaiaannya berdasarkan interpretasi yang dipahaminya. Sebanyak $26,9 \%$ siswa mampu menjawab soal ini dengan benar dan memperoleh skor penuh yang berarti bahwa mereka telah menguasai kemampuan level 4 PISA pada soal ini. 
- Gerhana matahan akan terjadi di Afrika Selatan s selandia Baru perbedaan waktu Afrika-Sel dengan Greenwich 2 Jam lebih cepat perbedaan waktu Selandia dengan Greenwich 13 Jam lebih cepat. gerhana matahari terjadi disiang hari;

misal gerhana matahari terjadi di Afrika Jam 12.00,

Jadi di Greenwich $=12-2=10.00$

$$
\text { di Selandia }=10+13=23.00 \text {, malam. }
$$

Jadi gerhana matahari "tdk bisi ter jadi di Afrika-Sel \& Selandia baru bersamaan krn waktu mereka bertolak belakang.

Gambar 1. Jawaban Siswa A

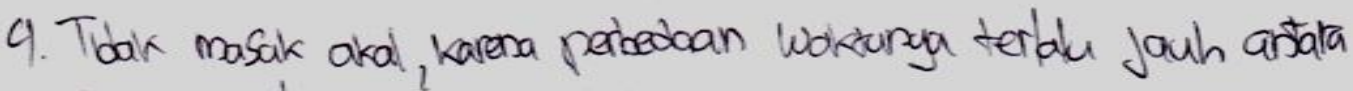
terika selatan dan selandla bara

Gambar 2. Jawaban Siswa B

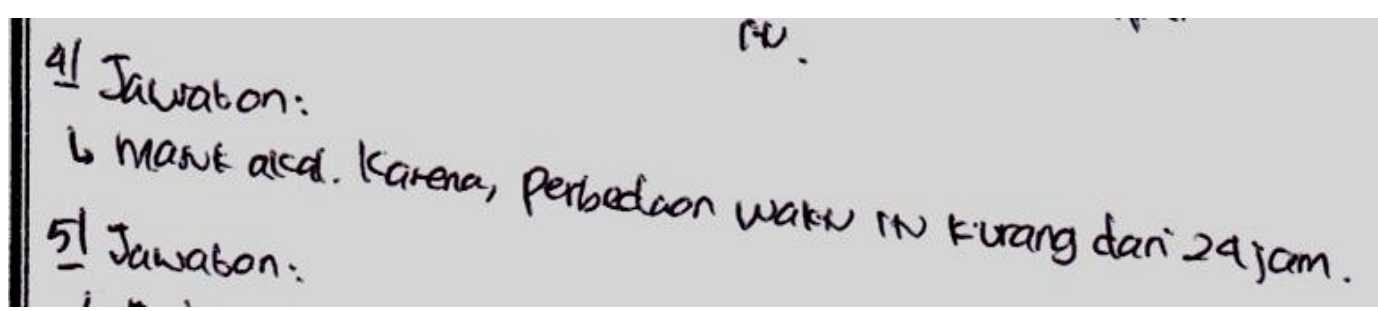

Gambar 3. Jawaban Siswa D

Siswa B menjawab soal ini dengan benar tetapi memberikan penjelasan yang kurang lengkap (Gambar 2). Siswa B telah mampu memahami informasi pada soal, yaitu perbedaan waktu antara Greenwich, Afrika Selatan, dan Selandia Baru serta menghubungkannya dengan kejadian gerhana matahari. Siswa B juga telah membangun dan mengomunikasikan penyelesaiannya berdasarkan interpretasinya. Namun, Siswa B belum mampu menggunakan kemampuan yang baik dalam memberikan alasan untuk mendukung jawabannya. Sebanyak 30,7\% siswa menjawab soal ini seperti jawaban Siswa B.

Sedangkan Siswa C menjawab soal ini dengan benar tanpa memberikan penjelasan. Ini menunjukkan bahwa Siswa C mampu memahami dan menghubungkan informasi pada soal tetapi Siswa $C$ tidak 
mengomunikasikan penyelesaiannya untuk memberikan alasan yang diperlukan untuk mendukung jawabannya. Ada 11,5\% siswa menjawab dengan benar tanpa alasan yang dapat mendukungnya. Siswa D salah dalam menjawab soal ini, tetapi dapat memberikan alasan yang mendukung jawabannya (Gambar 3). Sebanyak 30,8\% siswa salah menjawab soal ini seperti Siswa D. Mereka tidak menghubungkan peristiwa gerhana matahari dengan kenyataan bahwa gerhana matahari hanya bisa dilihat pada siang hari.

\section{Soal Nomor 2}

Ahli astronomi menyatakan: "Pada abad 21, gerhana matahari akan terjadi $\frac{16}{17}$ kali peristiwa dari abad $20 . "$

Berikut ini, manakah yang paling mencerminkan makna dari pernyataan ahli astronomi tersebut?

A. Kapan gerhana matahari akan terjadi tidak dapat diperkirakan, karena kita tidak dapat mengetahui apa yang akan terjadi di masa depan.

B. $\frac{16}{17} \times 100=94,12$, jadi ada kemungkinan akan terjadi 94 atau 95 gerhana matahari pada abad 21 .

C. $\frac{16}{17}$ kurang dari 1 , jadi gerhana matahari tidak akan terjadi pada abad 21 .

D. Diperkirakan pada abad 21, gerhana matahari yang terjadi lebih sedikit daripada abad 20.

Berikan penjelasan untuk mendukung jawabanmu!

\section{Konten : Ketidakpastian}

Konteks : Ilmiah

Para pakar sering membuat dugaan walaupun jarang dilakukan secara transparan atau eksplisit. Misalnya, pernyataan yang digunakan untuk meramalkan cuaca, seperti “peluang besok akan turun hujan adalah 20\%." Penonton atau pembaca akan berpikir bahwa besok kemungkinan besar akan panas, tetapi tidak bisa disalahkan jika akan terjadi hujan. 
JPM IAIN Antasari

Vol. 1 No. 1 Juli - Desember 2013, pp. 1-8

Siswa perlu mempertimbangkan pernyataan yang diberikan dan merefleksikan makna pernyataan tersebut ke dalam empat pilihan jawaban. Biasanya, pertanyaan seperti ini mensyaratkan siswa untuk menjelaskan hasil dari refleksi mereka dengan kata-katanya sendiri, tetapi jawaban seperti itu mungkin akan sulit untuk dinilai dengan objektif sehingga menggunakan format pilihan ganda. Siswa mungkin akan melakukan refkleksi dan mencoba untuk menghubungkan hasil proses refleksinya pada satu dari empat jawaban yang tersedia. Selain itu, siswa mungkin akan mempertimbangkan keempat jawaban, selanjutnya mencoba untuk menilai jawaban mana yang paling mungkin.

Sesuai dengan indikator soal level 4, soal ini mengharuskan siswa untuk bekerja secara efektif dengan pernyataan yang diberikan mengenai kejadian gerhana matahari pada abad ke-20 dan ke-21 yang disajikan berdasarkan konsep perbandingan. Siswa perlu memilih dan mengintegrasikan representasi yang berbeda dari pernyataan tersebut serta menghubungkannya secara langsung dengan aspek situasi dunia nyata mengenai kemungkinan terjadinya gerhana matahari. Mereka juga menggunakan kemampuan yang baik dalam beralasan secara fleksibel dengan beberapa pengetahuan mengenai konsep perbandingan dan peluang suatu kejadian untuk menentukan pilihan jawaban mana yang paling sesuai dengan pernyataan yang diberikan kemudian membangun dan mengomunikasikan penyelesaian berdasarkan argumen, interpretasi, dan tindakan mereka dalam memberikan penjelasan untuk mendukung jawaban mereka.

Siswa E menjawab soal ini dengan benar dilengkapi dengan alasan yang menyatakan bahwa $\frac{16}{17}$ kurang dari 1 sehingga gerhana yang terjadi pada abad 21 lebih sedikit daripada abad 20 seperti ditunjukkan Gambar 4. Siswa E telah mampu memahami pernyataan yang diberikan dengan baik dan benar serta telah mampu memilih dan mengintegrasikan pilihan jawaban yang benar dan menghubungkannya dengan pernyataan yang diberikan. Siswa E juga telah menggunakan kemampuan yang baik dalam 
Kamaliyah, Zulkardi, Darmawijoyo

beralasan sesuai dengan konsep perbandingan dan peluang di mana peluang suatu kejadian berkisar antara 0 sampai dengan 1 dan serta mampu mengomunikasikan penyelesaiannya berdasarkan konsep tersebut. Sebanyak 42,3\% siswa menjawab soal nomor 2 seperti jawaban Siswa E.

\section{5) Sayv jawab D. Diperkirahan abad 21 , gerharamatahon yarg
terjadikbih gedilit daripada abad 20 . horena 16 iten lebih sedihit daripada 1 , jodi 16 itu mengartiluan bah wa gerharo ahan terjail lebih sedimit davi abat 20.}

\section{Gambar 4. Jawaban Siswa E}

Sedangkan Siswa F menjawab soal ini dengan benar tanpa disertai alasan yang dapat mendukung jawabannya. Siswa $\mathrm{F}$ hanya mengemukakan alasan dengan mengulang kalimat pada pilihan jawaban yang dipilihnya. Hal ini menunjukkan bahwa Siswa $F$ belum memiliki kemampuan yang baik dalam memberikan alasan yang dapat mendukung jawabannya walaupun Siswa $\mathrm{F}$ mampu memahami dan menghubungkan informasi pada soal serta mengomunikasikan jawabannya. Ada 19,2\% siswa yang menjawab soal ini seperti Siswa F.

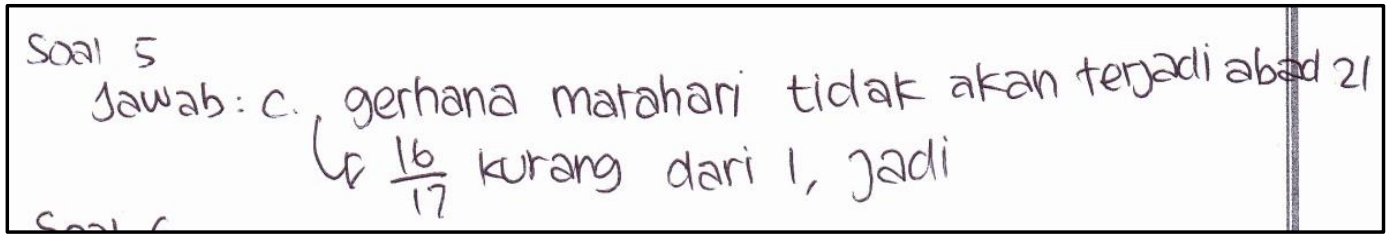

Gambar 5. Jawaban Siswa $G$

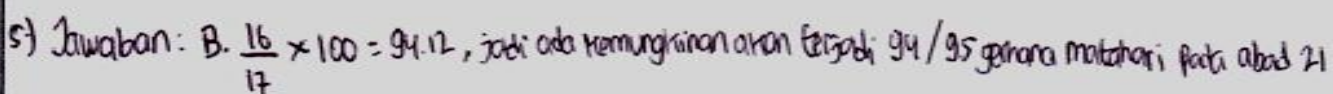

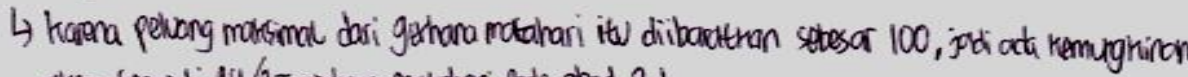
ahan Eergadi $14 / 95$ grihura matchari pada abad 21
}

Gambar 6. Jawaban Siswa H 
JPM IAIN Antasari

Vol. 1 No. 1 Juli - Desember 2013, pp. 1-8

Siswa $\mathrm{G}$ dan Siswa $\mathrm{H}$ memilih jawaban yang salah tetapi mereka memberikan alasan atas jawaban mereka. Siswa $G$ memilih jawaban $C$. Siswa $G$ kurang memahami konsep peluang di mana peluang kejadian yang kurang dari 1 bukan berarti bahwa kejadian itu tidak mungkin terjadi (Gambar 5). Sedangkan Siswa H memilih jawaban B yang menunjukkan bahwa Siswa $\mathrm{H}$ juga kurang memahami konsep peluang suatu kejadian dengan mengatakan bahwa peluang maksimal adalah 100 (Gambar 6). Kedua siswa tersebut belum memahami dengan baik pernyataan yang diberikan mengenai jumlah kejadian gerhana matahari pada abad ke-20 dan ke-21 yang disajikan berdasarkan konsep perbandingan serta menghubungkannya secara langsung dengan aspek situasi dunia nyata mengenai kemungkinan terjadinya gerhana matahari. Walaupun demikian, mereka menggunakan kemampuan dalam beralasan serta membangun dan mengomunikasikan penyelesaian untuk mendukung jawaban mereka. Ada $15,4 \%$ siswa yang salah menjawab soal ini.

\section{Kesimpulan}

Berdasarkan jawaban siswa dalam menyelesaikan soal matematika model PISA level 4, dapat disimpulkan bahwa siswa kesulitan dalam (1) memberikan penjelasan dan mengomunikasikannya berdasar pada interpretasi mereka, (2) menghubungkan representasi yang mereka peroleh dengan situasi dunia nyata. Siswa tidak kesulitan ketika bekerja secara efektif dengan model dalam situasi yang konkret tetapi kompleks, serta dalam memilih dan mengintegrasikan representasi yang berbeda.

\section{Daftar Pustaka}

Fraenkel J. R. \& Wallen N. E. (2010). How to Design and Evaluate Research in Education Seventh Edition. New York: McGraw-Hill.

Hayat, B., \& Yusuf, S. (2010). Mutu Pendidikan. Jakarta: Bumi Aksara.

OECD. (2009). Learning Mathematics for life: A View Persfective from PISA. Retrieved July 2011, from OECD web site: http://www.oecd.org 
Kamaliyah, Zulkardi, Darmawijoyo

OECD. (2010). PISA 2009 Results: What Students Know and Can Do. Retrieved July 2011, from OECD web site: http://www.oecd.org

OECD. (2013). PISA 2012 Results: What Students Know and Can Do. Retrieved December 2013, from OECD web site: http://www.oecd.org

Stacey, K. (2011). The View of Mathematical Literacy in Indonesia. Journal on Mathematics Education (IndoMS-JME), July 2011, Volume 2 , 124.

Tessmer, M. (1993). Planning and Conducting Formative Evaluations . Philadelphia: Kogan Page.

Wijaya, A. (2012). Pendidikan Matematika Realistik. Yogyakarta: Graha IImu.

Yusuf, S. (2007). Perbandingan Gender dalam Prestasi Literasi Siswa Indonesia. Retrieved Agustus 2011, from Uninus Web site: http://www.uninus.ac.id

\section{Kamaliyah}

IAIN Antasari, Banjarmasin

E-mail: kamaliy4h@gmail.com

\section{Zulkardi}

Universitas Sriwijaya, Palembang

E-mail: zulkardi@yahoo.com

\section{Darmawijoyo}

Universitas Sriwijaya, Palembang

E-mail: darmawijoyo1965@gmail.com 